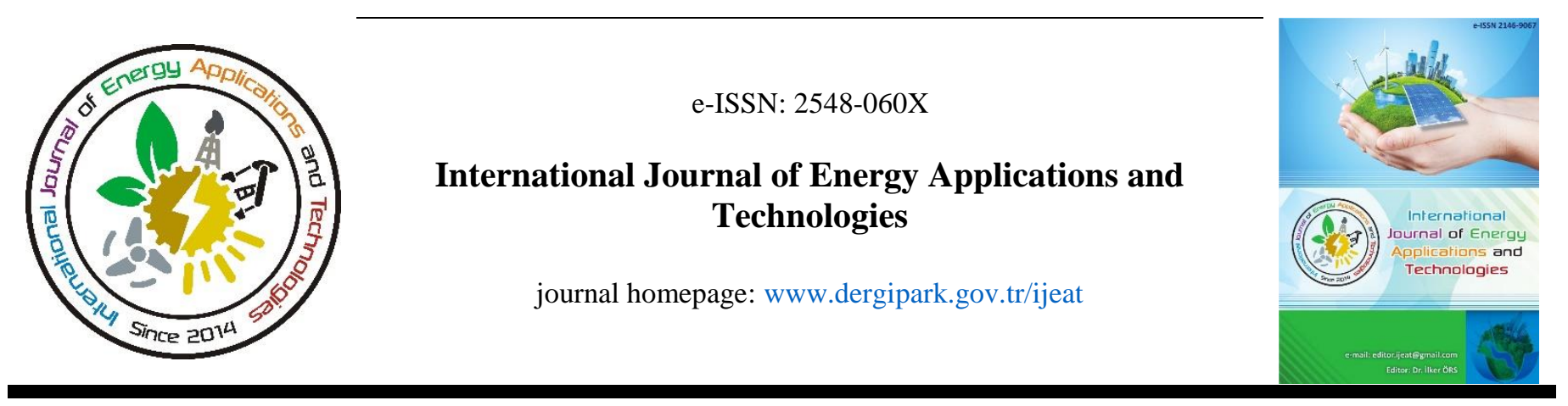

Original Research Article

\title{
Fracture energy comparison of aluminum and boron composites for fuel cell end plates
}

\author{
Adem Avcu*, Naghdali Choupani, Gökhan Tüccar \\ ${ }^{I}$ Mechanical Engineering Department, Faculty of Engineering, Adana Alparslan Türkeş Science and Technology University, Adana Turkey
}

\author{
ARTICLE INFO \\ * Corresponding author \\ ademavcu01@gmail.com \\ Received September 19, 2020 \\ Accepted December 1, 2020 \\ Published by Editorial Board \\ Members of IJEAT \\ (C) This article is distributed by \\ Turk Journal Park System under \\ the CC 4.0 terms and conditions. \\ doi: 10.31593/ijeat.795403
}

\begin{abstract}
Fuel cells have become an attractive choice because they do not cause environmental and noise pollution. Additionally, they do not contain any moving parts and have higher efficiency than fossil fuels. Therefore, improving the capability of fuel cells helps to provide clean energy. Among fuel cells, the proton exchange membrane fuel cell (PEMFC) includes five main parts that are end plate, membrane, gas diffusion layer (GDL), catalyst layer (CL), bipolar flow plate (BFP). End plates hold PEMFC parts together securely. They should have high mechanical strength and low density properties. Therefore, the choice of materials for the PEMFC endplate is important. The calculated values of fracture energy show quantitatively how much energy must be placed in the sample to create the fracture surface. In this study, a finite element study was performed to understand the fracture behavior of cracks in the selected materials under different loading angles. The results revealed that the total fracture energy of aluminum was higher than boron-aluminum 50 and boron-aluminum 65 composites.
\end{abstract}

Keywords: Composite material; End plate; Fracture energy; Fuel cell

\section{Introduction}

Nowadays, the increasing need for energy has led people to research and develop clean energy. Fuel cells are seen as an important option among clean energy sources with their positive aspects. They have advantages over batteries such as; clean, quiet and efficient operation; ability of continuous electricity generation without recharging. Fuel cells are electrochemical devices that operate with the principle of reversing water electrolysis to generate electricity by chemical processes. There are many types of fuel cells but Proton Exchange Membrane Fuel Cell (PEMFC) due to its high efficiency and simple structure, is more environmentally friendly.With the advancement of technology, the use of fuel cells is expanding in more areas [1-3]. Fuel cells also have a wide range of areas of use including transportation, power generation, space, marine and aviation [4-6].
Fuel cells are composed of different components. The main parts of fuel cells are catalyst layer (CL), gas diffusion layer (GDL), membrane, bipolar flow plate (BFP) and end plate. The detailed parts of the PEMFC are shown in Fig. 1.

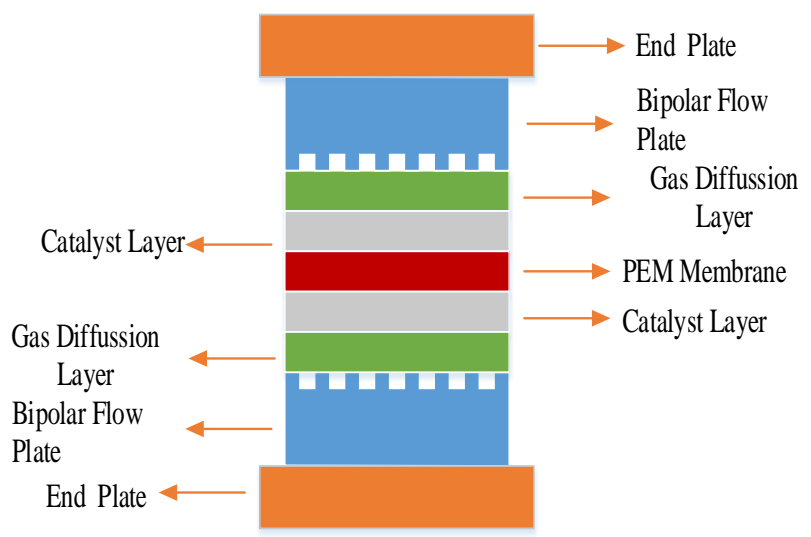

Fig. 1. PEMFC parts 
The chemical reactions which are necessary to produce electricity occur within the membrane electrode assembly (MEA), which includes the membrane, the catalyst layers, and gas diffusion layers. Metal, non-metal and composite materials are used as the proposed materials in fuel cells. Composite materials are also preferred due to their lightness, corrosion resistance and high mechanical properties in fuel cells [7]. Although there are studies with composite bipolar flow plates, there are few studies on end plates in this field [8-14]. End plates of PEMFC hold stacks together and ensure safe and ideal working conditions. Additionally, it provides a compressive force that is named the clamping pressure. If the applied pressure is insufficient, there may be fuel leakage, poor electrical conductivity and reduced efficiency. If it is excessive, there may be a decrease in transfer mass, an increase in flooding in GDL, and a decrease in efficiency. In addition, the end plates must have low density, sufficient mechanical strength, resistance to chemical corrosion and electrical insulation. Therefore, the choice of materials is a key issue to ensure ideal working conditions. Generally, nonmetals, metals and composite materials are used as end plate. Aluminum has a low density and high strength. The lower the density and the higher the strength-to-weight ratio of this material is ideal for PEMFC end plates. Composite materials also have high stiffness, strength and lightness, these properties have made them suitable for use in various fields. In this article, in order to select the suitable material for end plate; aluminum and boron composites have been investigated in terms of their fracture energies [15-20, 21]. The calculated $G$ values of fracture energy indicate durability, indicating quantitatively how much energy must be placed in the sample to create fracture levels. When different loads are applied to the specimen, it is significant to determine what kind of failure may occur. There are three fracture modes which are mode I (opening), mode II (sliding shear) and mode III (tearing) [20]. The fracture modes are shown in Fig. 2. There are many methods in order to determine the fracture energy, but the arcan specimen provides estimation of mode I, mode II and mixed mode fracture conditions [12, 13, 21].
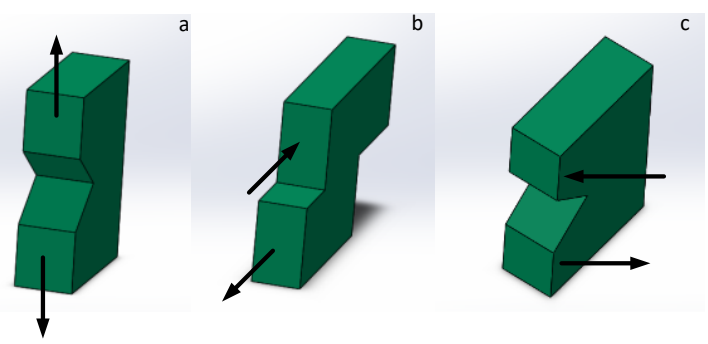

Fig. 2. Fracture modes, (a) mode I, (b) mode II, (c) mode III

Generally, composites and metals can be used as an end plate material. A finite element study was performed to understand the fracture behavior of cracks in the PEMFC end plate selected materials. Numerical analysis of modified Arcan specimen was studied for aluminium and its composite with boron material based on volume fraction of 50 and $65 \%$ as the PEMFC end plate material. $G_{I}, G_{I I}$ and $G_{T}$ were obtained by using numerical data for different materials under various loading conditions and the results were compared.

\section{Material and Methods}

In PEMFC fuel cells, an end plate is used to hold the stacks together. Metal, non-metal or composite materials can be used for the end plates [15]. In this study, aluminum and two different aluminum boron composite materials are investigated as the PEMFC fuel cells end plate material [22, 23]. Elastic parameters of the materials used in this analysis are listed in Table 1. In the first step, stress intensity factors were obtained numerically using Abaqus commercial software for different angles under mode I, mode II and mixed mode by using the applied load of $1000 \mathrm{~N}$. Then the fracture energies of different materials were calculated under mixed loading conditions. Arcan specimen modelling is shown in Fig. 3. The small part of arcan specimen was considered to evaluate fracture energy of different materials.

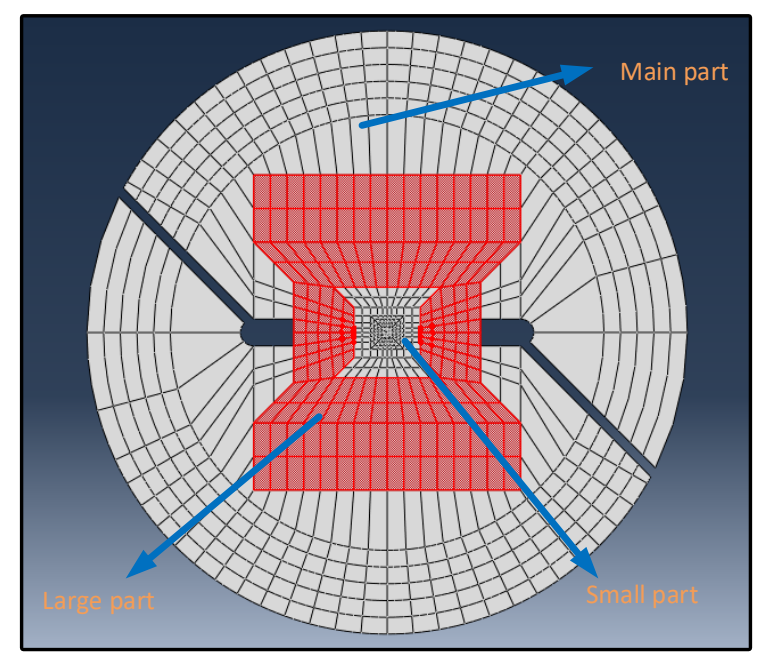

Fig. 3. Arcan specimen modelling in Abaqus

The fracture energy for isotropic material can be obtained from the following equations [8].

$$
\begin{aligned}
& G_{I}=K_{I}^{2} / \bar{E} \\
& G_{I I}=K_{I I}^{2} / \bar{E}
\end{aligned}
$$

Where $E$ is the modulus of elasticity, $v$ is the Poisson's ratio and $K_{I}$ and $K_{I I}$ are the state I and state II stress intensity factors for plane strain conditions, respectively [8].

$$
\bar{E}=E /\left(1-v^{2}\right)
$$

Fracture energy for orthotropic composite materials can be calculated from the following equations [11].

$$
\begin{aligned}
& G_{I}=K_{I}^{2} / E_{I} \\
& G_{I I}=K_{I I}^{2} / E_{I I}
\end{aligned}
$$


where $K_{I}$ and $K_{I I}$ are mode-I and mode-II stress intensity factors, respectively. The specimens are assumed to be orthotropic linear elastic materials and the effective modulus of $E_{I}$ and $E_{I I}$ are given below [11].

$$
\begin{aligned}
& E_{I}=\sqrt{\frac{2}{b_{11} b_{22}}} \frac{1}{\sqrt{\sqrt{\frac{b_{22}}{b_{11}}+\frac{2 b_{12}+b_{66}}{2 b_{11}}}}} \\
& E_{I I}=\frac{\sqrt{2}}{b_{11}} \frac{1}{\sqrt{\sqrt{\frac{b_{22}}{b_{11}}+\frac{2 b_{12}+b_{66}}{2 b_{11}}}}}
\end{aligned}
$$

\begin{tabular}{|c|c|c|c|}
\hline Material & Aluminum & $\begin{array}{c}\text { Boron- } \\
\text { Aluminum65 }\end{array}$ & $\begin{array}{c}\text { Boron- } \\
\text { Aluminum50 }\end{array}$ \\
\hline $\mathrm{E}_{1}[\mathbf{G P a}]$ & 72 & 297 & 244 \\
\hline $\mathbf{E}_{2}[\mathbf{G P a}]$ & 72 & 211 & 168 \\
\hline $\mathbf{E}_{3}[\mathrm{GPa}]$ & 72 & 211 & 168 \\
\hline $\mathbf{G}_{12}[\mathrm{GPa}]$ & 27 & 82 & 64 \\
\hline $\mathbf{G}_{13}[\mathrm{GPa}]$ & 27 & 82 & 64 \\
\hline $\mathbf{G}_{23}[\mathbf{G P a}]$ & 27 & 317 & 253 \\
\hline$v_{12}$ & 0.33 & 0.24 & 0.26 \\
\hline$v_{13}$ & 0.33 & 0.24 & 0.26 \\
\hline$v_{23}$ & 0.33 & 0.33 & 0.33 \\
\hline
\end{tabular}

Table 1. Elastic properties of metal and composite materials

2D numerical analyzes were performed using ABAQUS finite element software for different materials under mixed mode loading conditions. Since the mesh pattern of the whole arcan specimen model is shown in Fig. 3, the whole fixture was meshed using eight nodes of the four collapsed elements of the model (CPE8RH). The mesh was refined around the crack tip as shown in Fig. 4, and linear elastic finite element analysis was performed under the plane strain conditions using the singularity of the stress field. Then the values of stress intensity coefficients and corresponding fracture energies were calculated.

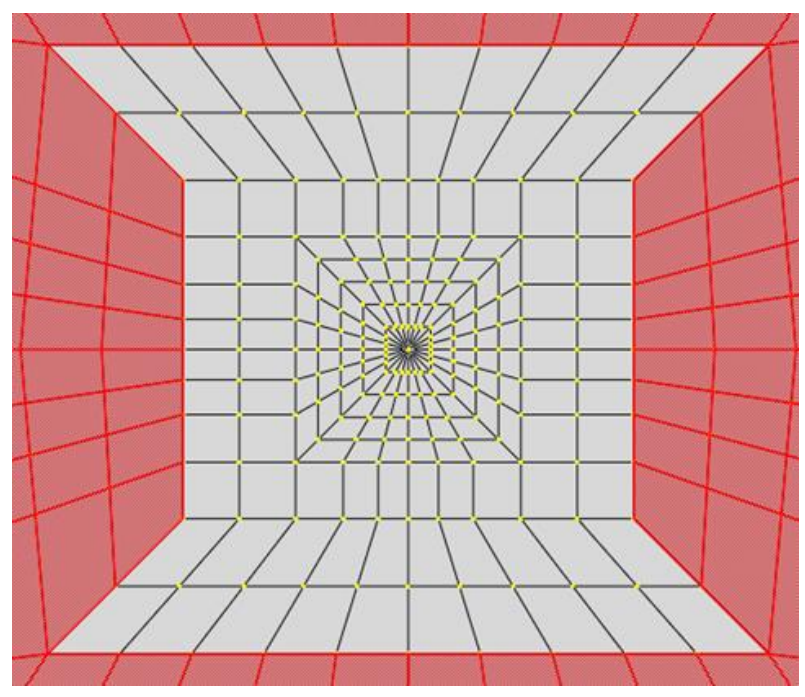

Fig. 4. Refined mesh pattern of arcan specimen

\section{Results and Discussion}

The relationship between the mode I $\left(G_{I}\right)$, mode II $\left(G_{I I}\right)$, total $G_{T}=G_{I}+G_{I I}$ and the ratio of fracture energy $\left(G_{I I} / G_{I}\right)$ of materials are given in Figs. 5-8, respectively. The effect of fuel cell end plate materials on fracture behavior were investigated by using arcan specimen under different loading angles. The problem was solved by considering materials with different properties. The results are shown in Figs. 5-7 where $G_{I}, G_{I I}$ and $G_{T}$ are shown versus loading angles for different materials. Materials with different properties showed significant effects on fracture energy at the crack tip. The difference between the fracture energy of the opening mode decreases but the difference between the fracture energy of the shear mode increases with increasing loading application angle. The total fracture energy for the loading angle close to the tensile load state increases rapidly as the stiffness of the material decreases, and the difference decreases as the load-sharing ratio of shear mode increases. Therefore, as the materials become stiffer, the arcan sample is more resistant to failure (by lowering the total fracture energy). The relationship between the mixed mode ratio of fracture energy and the loading angle is shown in Fig. 8. For loading angles close to the tensile load state, very small ratios from mode II to mode I are dominant. The ratio of fracture energy close to the shear load of mode II shows the opposite trend.

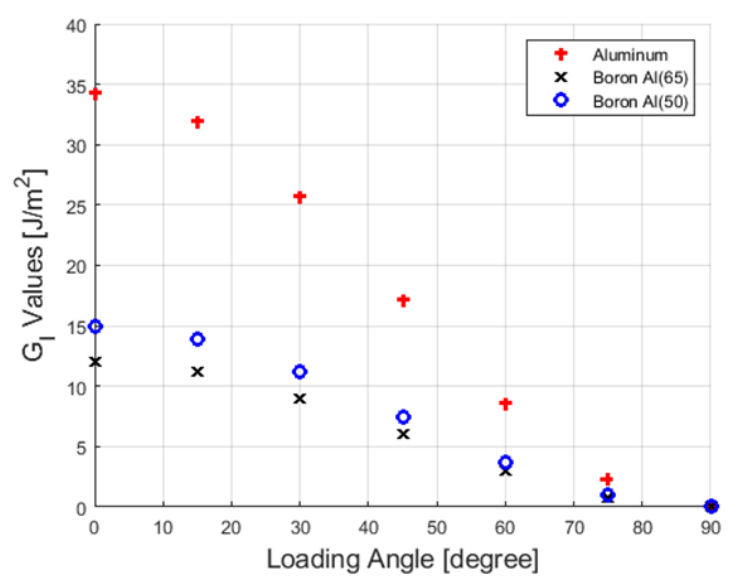

Fig. 5. $G_{I}$ versus loading angle graph

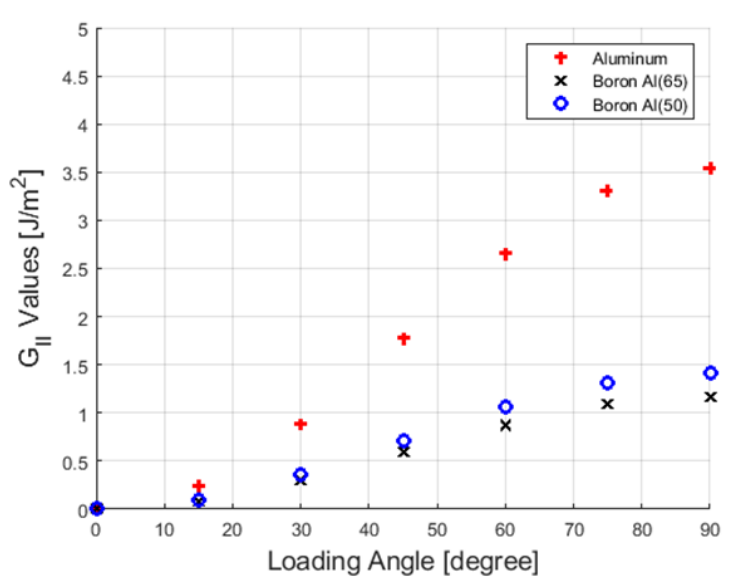

Fig. 6. $G_{I I}$ versus loading angle graph 


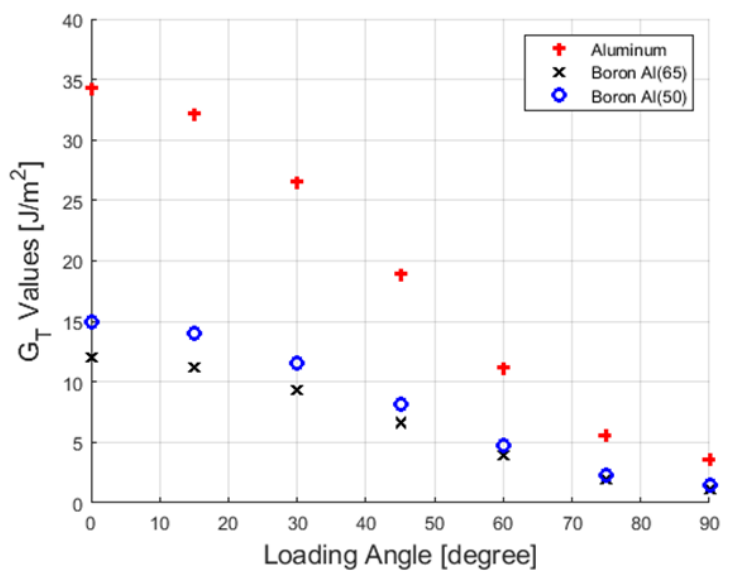

Fig. 7. $G_{T}$ versus loading angle graph

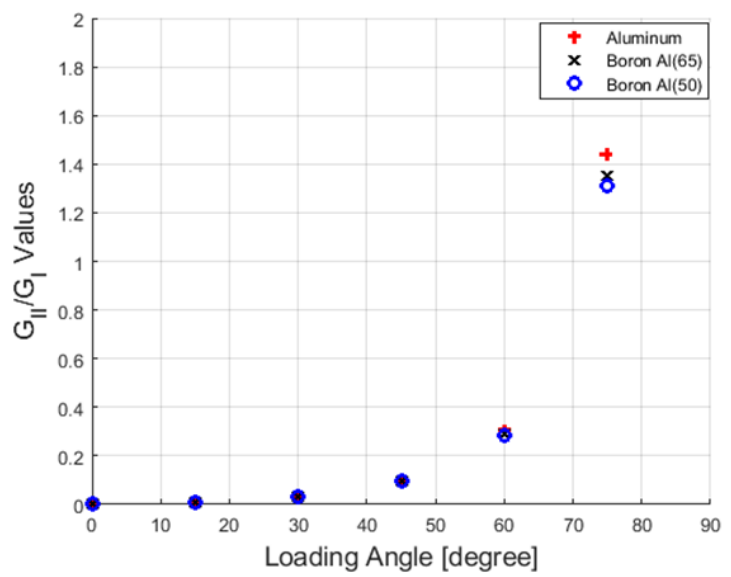

Fig. 8. $\mathrm{G}_{\mathrm{II}} / \mathrm{G}_{\mathrm{I}}$ (logaritmic) versus loading angle graph

In Table 2, it can be seen that by decreasing the effective modulus of elasticity, the shear, the opening, and total fracture energy increases. The total fracture energy of aluminum is higher than of Boron-Aluminium50 and BoronAluminium65 composites, which reduces the fracture resistance of these material. The use of composite materials in engineering applications is expanding due to performance improvements that can be achieved with weight loss.

Table 2 Fracture energy of Aluminum and composite materials

\begin{tabular}{cccc}
\hline Material & $\begin{array}{c}\text { Boron- } \\
\text { Aluminum65 }\end{array}$ & $\begin{array}{c}\text { Boron- } \\
\text { Aluminum50 }\end{array}$ & Aluminum \\
\hline $\mathbf{G}_{\mathbf{I}}\left[\mathbf{J} / \mathbf{m}^{2}\right]$ & 11.97 & 14.93 & 34.27 \\
$\mathbf{G}_{\mathrm{I}}\left[\mathbf{J} / \mathbf{m}^{2}\right]$ & 1.17 & 1.41 & 3.55 \\
$\mathbf{G}_{\mathbf{T}}\left[\mathbf{J} / \mathbf{m}^{2}\right]$ & 13.14 & 16.34 & 37.82 \\
\hline
\end{tabular}

In this study, a numerical attempt has been made to explain some of the important issues related to the fracture energy in the mixed mode state of the fuel cell end plates, and due to the importance of the problem, significant work is still needed in this field. In order to expand the understanding of fracture behavior and to determine more precisely the criterion of failure of the fuel cell end plates, other numerical and experimental work should be done.

\section{Conclusion}

In this paper, the strain energy release rates of aluminum and aluminum boron composites were investigated by numerical analysis of arcan specimen. Then fracture energy was obtained for the materials under investigation. When examining aluminum, it has the highest values of $G_{I}, G_{I I}$ and $G_{T}=G_{I}+G_{I I}$ compared to other materials selected for this study. For loading angle close to mode I condition, values of mode I fracture is dominant. In addition, the total fracture energy is reduced under mixed loading conditions as the loading angle increases. In loading angles close to mode II condition, the shear mode is dominant. The relationship between the mixed-mode ratios of fracture energies and the loading angles was also presented. The total fracture energy for the Boron-Aluminium65 composite was less than that of Aluminum and Boron-Aluminum50 composite, which increases the fracture resistance of these materials.

\section{$\underline{\text { ORCID }}$}

Adem Avcu

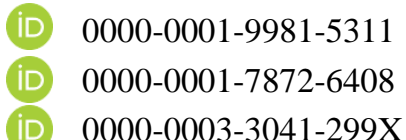

Gökhan Tüccar

0000-0003-3041-299X

\section{References}

[1] Bayrak Z.U., Gençoğlu M.T. (27-30 June 2010) Mathematical Models of PEM Fuel Cells 5th International Ege Energy Symposium and Exhibition (IEESE-5) Pamukkale University, Denizli, Turkey

[2] Giorgi, L., \& Leccese, F. (2013). Fuel cells: technologies and applications. The Open Fuel Cells Journal, 6(1).

[3] Haile, S. M. (2003). Fuel cell materials and components. Acta Materialia, 51(19), 5981-6000.

[4] Wee, J. H. (2007). Applications of proton exchange membrane fuel cell systems. Renewable and sustainable energy reviews, 11(8), 1720-1738.

[5] Gencoglu, M. T., \& Ural, Z. (2009). Design of a PEM fuel cell system for residential application. International Journal of Hydrogen Energy, 34(12), 5242-5248.

[6] Van Biert, L., Godjevac, M., Visser, K., \& Aravind, P. V. (2016). A review of fuel cell systems for maritime applications. Journal of Power Sources, 327, 345-364.

[7] Baroutaji A., Carton J.G., Sajjia M., Olabi A.G. (October 2015) Materials in PEM Fuel Cells Materials Science and Materials Engineering DOI: 10.1016/B978-0-12-803581-8.04006-6

[8] Tamilarasan, U., Karunamoorthy, L., \& Palanikumar, K. (2015). Mechanical properties evaluation of the carbon fibre reinforced aluminium sandwich composites. Materials Research, 18(5), 1029-1037.

[9] Yu, H. N., Kim, S. S., \& Do Suh, J. (2010). Composite endplates with pre-curvature for PEMFC (polymer 
electrolyte membrane fuel cell). Composite Structures, 92(6), 1498-1503.

[10] Hermann, A., Chaudhuri, T., \& Spagnol, P. (2005). Bipolar plates for PEM fuel cells: A review. International journal of hydrogen Energy, 30(12), 1297-1302.

[11] Wilberforce, T., El Hassan, Z., Ogungbemi, E., Ijaodola, O., Khatib, F. N., Durrant, A., ... \& Olabi, A. G. (2019). A comprehensive study of the effect of bipolar plate (BP) geometry design on the performance of proton exchange membrane (PEM) fuel cells. Renewable and Sustainable Energy Reviews, 111, 236-260.

[12] Choupani, N. (2008). Experimental and numerical investigation of the mixed-mode delamination in Arcan laminated specimens. Materials Science and Engineering: A, 478(1-2), 229-242.

[13] Abadi R.H., Torun A.R., Fard A.M.Z., Choupani N. (2020) Fracture characteristics of mixed-mode toughness of dissimilar adherends (cohesive and interfacial fracture) Journal of Adhesion Science and Technology https://doi.org/10.1080/01694243.2019.1674102

[14] Kumar, A., \& Reddy, R. G. (2004). Materials and design development for bipolar/end plates in fuel cells. Journal of Power Sources, 129(1), 62-67.

[15] Kim, J. S., Park, J. B., Kim, Y. M., Ahn, S. H., Sun, H. Y., Kim, K. H., \& Song, T. W. (2008). Fuel cell end plates: a review. International Journal of Precision Engineering and Manufacturing, 9(1), 39-46.

[16] Asghari, S., Shahsamandi, M. H., \& Khorasani, M. A. (2010). Design and manufacturing of end plates of a 5 $\mathrm{kW}$ PEM fuel cell. International journal of hydrogen energy, 35(17), 9291-9297.

[17] Wang, X., Song, Y., \& Zhang, B. (2008). Experimental study on clamping pressure distribution in PEM fuel cells. Journal of Power Sources, 179(1), 305-309.

[18] Hwang, J. J., Chang, W. R., Weng, F. B., Su, A., \& Chen, C. O. K. (2008). Development of a small vehicular PEM fuel cell system. International Journal of Hydrogen Energy, 33(14), 3801-3807.

[19] Pozio, A., Silva, R. F., De Francesco, M., \& Giorgi, L. (2003). Nafion degradation in PEFCs from end plate iron contamination. Electrochimica acta, 48(11), 1543 1549.

[20] Bhat M.A., Shaikh A. A. (2014) FEA simulation and geometric calibration of Arcan fixture for butterfly specimen of RP material International Journal of Engineering and Technical Research (IJETR) ISSN: 2321-0869, Volume-2, Issue-10, October 2014

[21] Choupani N. (2006) Mixed Mode I/II Interlaminar Fracture of $\mathrm{CF} / \mathrm{PEI}$ Composite Material Journal of Aerospace Science and Technology JAST, Vol. 3, No. 4, pp185-193
[22] Choupani, N. (2009). Characterization of fracture in adhesively bonded double-lap joints. International Journal of Adhesion and Adhesives, 29(8), 761-773.

[23] Salam, S. S., Mehat, N. M., \& Kamaruddin, S. (2019, August). Optimization of Laminated Composites Characteristics via integration of Chamis Equation, Taguchi method and Principal Component Analysis. In IOP Conference Series: Materials Science and Engineering (Vol. 551, No. 1, p. 012110). IOP Publishing. 